\author{
Associate Professor Emilija Beker PUCAR, PhD \\ E-mail: emilijabp@gmail.com \\ Department of International and European Economics and Business \\ University of Novi Sad, Faculty of Economics in Subotica \\ Assistant Professor Olgica GLAVAŠKI, PhD \\ E-mail: glavaški.olgica@gmail.com \\ Department of International and European Economics and Business \\ University of Novi Sad, Faculty of Economics in Subotica
}

\title{
NON-STATIONARY HETEROGENEOUS PANEL APPROACH OF CURRENT ACCOUNT ADJUSTMENTS IN THE EURO-AREA
}

\begin{abstract}
The paper contributes to the vast literature dealing with the Euro-Area (EA) (un)sustainability by focussing the external (current account) position of initial EA12 members in dependence from national price dynamics and supranational nominal (euro) exchange rate. Under the empirical framework of heterogeneous non-stationary panel model, the dependent variable of current account is estimated in dependence from price dynamics and nominal (euro) exchange rate in the period 1999Q1-2019Q4. The results obtained with preferred Polled Mean Group (PMG) estimator indicate that current account position expectedly worsens in the long run if euro appreciates and domestic inflation increases. Short-run dependence is, however, heterogeneous across individual EA12 members. The convergence of external balance between the EA12 members could be threatened in the light of insignificant error-correction term in the case of the peripheral countries. Thus, our findings underpin the' core-periphery dualism' within the EA in the sense of diverging external adjustment.

Keywords. Euro-area, current account, price dynamics, nominal euro exchange rate, heterogeneous panels, core, periphery, PMG.
\end{abstract}

JEL classification: E52, E58, E61, F45

\section{Introduction}

The Euro-Area (EA) as a rigid monetary framework operates under almost impossible circumstances of unfulfilled conditions of OCA criteria, rigid labor market, divergent economic cycles, without fiscal transfers and with a desparate need for deeper fiscal and political integration. The members of a monetary union lose monetary autonomy assuming that interest rate and exchange rate channels operate under the common framework. However, if other national economic instruments operate with excessive discretionary space and without necessary

DOI: $10.24818 / 18423264 / 55.1 .21 .12$ 


\section{Emilija Beker Pucar, Olgica Glavaški}

discipline in regards to rigid monetary framework, asymmetries arise leading towards monetary union unsustainability.

The heterogeneouty of the EA is well known and widely investigated topic in research papers. We try to contribute to this literature by focusing the external position of the EA members, which is perceived as divergent in the relationship between the core vs. the periphery. However, it is interesting to highlight this kind of macroeconomic external asymmetry from the aspect of the long-run and the short-run dynamics, as well as adjustments towards the equilibrium from the angle of the EA per se, as well as EA members in concreto. Thus, sample consists from 12 initial EA members, often referred as the core (Austria, Belgium, Finland, France, Germany, Luxembourg, Netherlands) and the periphery (Greece, Portugal, Spain, Ireland, Italy) in the period 1999Q1-2019Q4. Current account, as an indicator of national external position, is related with domestic price dynamics (as national competetiveness and divergence indicator) from one side and common nominal (euro) exchange rate (as supranational competetiveness indicator) from the other side. Since the convergence process is in the root of the EA, long-run causal relationship and cointegration have been expected, but also the heterogeneity at the level of individual EA members. These expectations are checked and analyzed in more details on the basis of heterogeneous, dynamic and non-stationary panel framework. PMG estimator will provide insights into homogeneous coefficients and error correction terms in the long run at the EA level, as well as heterogenenous short-run coefficients and error-correction parameters at the level of individual EA12 members.

The paper is structured as follows: after introduction section, key macroeconomic imbalances with the focus towards external imbalances of selected EA members are emphasized in the second section; the third section presents the methodological framework which is exposed through the research sample, the period, the variables and panel ARDL model (PMG and MG estimators); in the section four the results are shown, first of all in the form of pre-estimation procedure, followed with discussion of key empirical findings of PMG estimation; finally, section five concludes with key insights concerning the investigated issue.

\section{Macroeconomic divergences and current account positions within the EA: Literature survey and descriptive analysis}

Macroeconomic divergence within the EA is widely recognized in the sense of internal balance (inflation and real economy) as well as external (current account position) balance. It is a well-known fact that countries in the EA are extremely heterogeneous from an economic viewpoint since countries with large current account surpluses, high GDP per capita levels and growth rates, coexist with others faring worse in these indicators (Bonatti and Fracasso, 2017; De Grauwe, 2018). Focusing the attention towards current account divergence in the EA, large and chronic deficit of one group of countries (Spain, Greece, Portugal, Italy and Ireland) from one side (the periphery), and the surplus of another group of

186

DOI: $10.24818 / 18423264 / 55.1 .21 .12$ 
Non-Stationary Heterogeneous Panel Approach of Current Account Adjustments in the Euro-Area

countries (Germany, France, Belgium, Netherlands, Finland, Austria, Luxembourg) from the other side (the core) could be observed (Figure 1). This divergence culminated prior the global 2008 crisis between the core and the periphery, while crisis-driven external adjustment followed in the post-crisis period. However, postcrisis external convergence between the core and the periphery was mostly the burden of the peripheral EA members, while the surpluses remain at pre-crisis levels (Estrada et al, 2013; Beker Pucar and Glavaški, 2020b). Most current account deficit countries have managed to improve their competitiveness and turned their deficits into balanced or surplus positions. Notwithstanding the significant adjustment in flow imbalances, as Pierluigi and Sondermann (2018) point out, several stock variables (private or public debt, net foreign assets position) remain elevated in the EA.

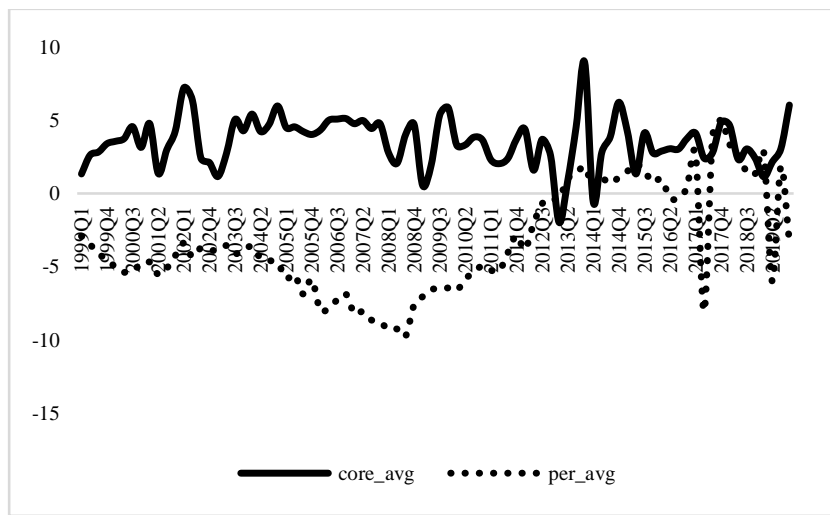

Note: $c o r e \_a v g$ - average for the core; per_avg - average for the periphery.

Source: authors according the quarterly data of IMF International Financial Statistics.

\section{Figure 1. Current account of the EZ core and the periphery in the period 1999-2020}

The question is how this apparent current account deficit of the periphery and surplus of the core was maintained since the beginning of the EA, and how it still presents an important diverging factor. In revealing this vulnerability point of the EA, several related issues arise: inflation divergence, different growth models of the members states, external and automatic adjustment mechanism in the monetary union, jeopardized competitiveness of the periphery, strong trade and financial linkages between members, etc. However, the root of the problem is inflation divergence between members of the monetary union. In order to maintain the competetiveness in the monetary union where developed and highly competitive European economies participate and share the common currency, national price dynamics should be under control. The stability of the monetary union implies the uniformity of the price dynamics among member states 


\section{Emilija Beker Pucar, Olgica Glavaški}

(Karanasos et al, 2016). In the run-up to the establishment of the EA, a marked process of convergence took place among all the countries that had decided to enter the common currency zone. Peripheral countries particularly succeeded in lowering their inflation and government deficits through contractionary economic policy, although initially these economies didn't meet the requirements for admission (Acocella and Pasimeni, 2018). However, after admission, inflation rose practically in all countries, but particularly in peripheral EA members (Figure 2).

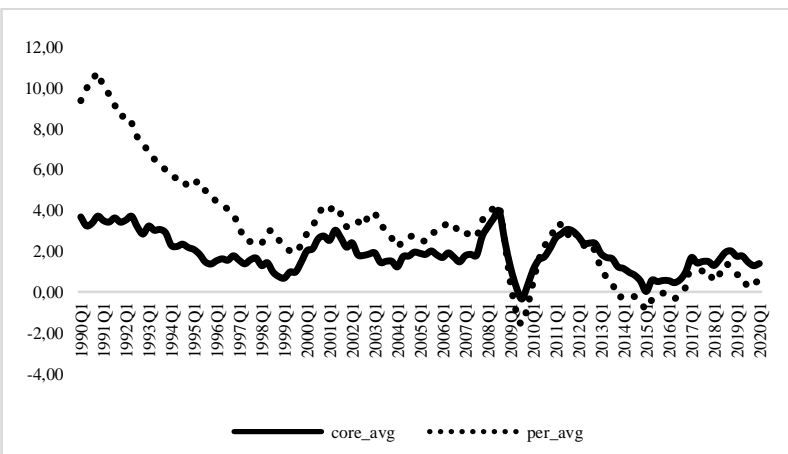

Note: $c o r e \_a v g$ - average for the core; per_avg - average for the periphery.

Source: authors according the quarterly data of IMF International Financial Statistics.

Figure 2. Average inflation rate for the EZ core and periphery in the period 1990-2020

Since nominal (euro) exchange rate is unified, the only way to improve competitiveness (i.e. initiate real exchange rate depreciation) is via deflationary mechanism (internal devaluation) or the national price channel. Another channel is EA exchange rate channel relying on nominal (euro) exchange rate depreciation, but this channel is out of discretionary space of national economic authorities. The inflation differentials along with the common (euro) nominal exchange rate initiate the divergence of members' real exchange rates (Figure 3). Until the formation of the EA in 1999, real exchange rates of peripheral countries recorded appreciation tendency as a sign of deteriorated competitiveness. Core countries have had lower inflation and higher real exchange rate, with consequently favourable competitiveness and current account position (Tokarski, 2019). With the exception of real exchange rate convergence in the years following the global crisis, it is clear that since the euro introduction real exchange rates of the periphery have inclined towards appreciation, thus worsening their competitiveness. 
Non-Stationary Heterogeneous Panel Approach of Current Account Adjustments in the Euro-Area

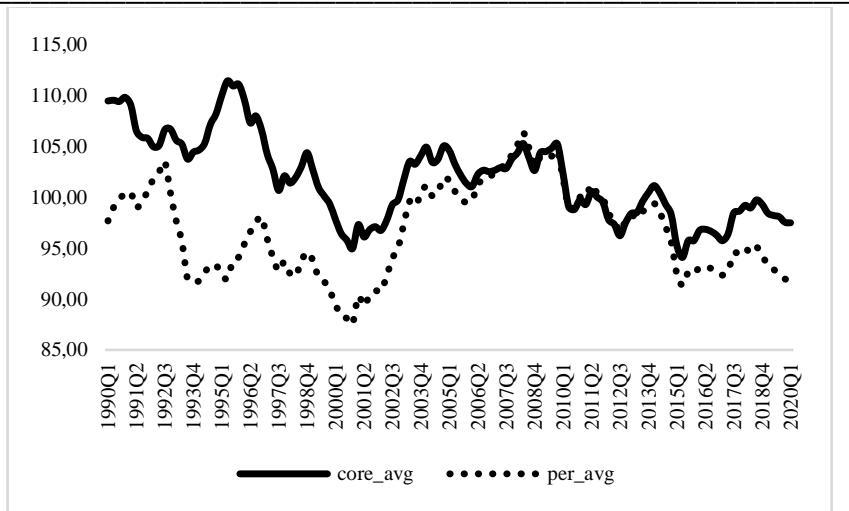

Note: core_avg - average for the core; $p e r \_a v g$ - average for the periphery.

Source: authors according the quarterly data of IMF International Financial Statistics.

Figure 3. Real effective exchange rate of the EA core and the periphery in the period 1990-2020

Under rigid monetary framework automatic stabilizers or mechanisms involve deflationary adjustment for the countries with chronic current account deficit and inflationary adjustment for the countries with the current account surplus. This kind of adjustment is especially painful for deficit EA members (dominantly peripheral countries) since it involves internal devaluation, accompanied with output losses and unemployment rise (Beker Pucar and Glavaški, 2020a; Marjanac, 2020). However, this automatic adjustment mechanism was avoided and delayed, further establishing the external divergence within the EA. Necessary real exchange rate depreciation in the periphery, in order to retain external sustainability in the long run, was omitted due to capital inflows from core countries (Chen et al, 2012). Namely, the EA is based on strong trade and financial linkages, leading towards lower correlation between national saving and investment. The combination of less developed economy (periphery) with growing current account deficit is, in a certain extent, understandable and expected. Economically weaker countries have better growth perspectives (less saving) and expected higher capital returns (higher investments) (Blanchard and Giavazzi, 2002). Countries with lower real interest rate (supranational nominal interest rate and higher national inflation) attracts capital from the core, accompanied with higher credit demand, investment, with further inflationary pressures and macroeconomic overheating (Lane and McQuade, 2013). The relation between current and capital account of the EA members, as well as inflation divergences, shouldn't be observed independently from the two different (but interlinked) growth models. Credit-led growth of the periphery vs. export-led growth in the core, have generated persistent inflation divergences, consequently divergences in real exchange rates, competitiveness and current account position (external

DOI: 10.24818/18423264/55.1.21.12 


\section{Emilija Beker Pucar, Olgica Glavaški}

balance). Growing financial integration between EA members made possible the channeling of the core surplus (excess of savings over investments) towards higher inflationary periphery, thus fuelling overall macroeconomic divergence (Johnston and Regan, 2016).

\section{Methodological framework}

\subsection{The variables, the period and the sample}

National current accounts of the EA12 members are brought into a connection with domestic price level as the determinant of national competitiveness and with nominal euro exchange rate as supranational indicator of competitiveness.

As well known, joining the monetary union induces the sacrifice of monetary autonomy including the role of exchange rate as a shock absorber. The EA members can no longer use nominal exchange rate depreciation as an adjustment mechanism towards competitiveness improvement. Instead, nominal exchange rate is unified at the EA level in the form of nominal euro exchange rate. If euro nominally weakens then the current account position of the EA members should improve. However, this relation is not simple, homogeneous and straightforward. In this research the authors try to reveal the influence of common nominal (euro) exchange rate to the current account (or external) position for the each of examined EA12 members. Close short-run and long-run connectedness, including adjustment towards equilibrium (error correction term) is plausible for the EA sustainability. Otherwise, heterogeneous and weak connection between this supranational variable and national current accounts, with the absence of adjustment mechanism towards equilibrium, presents one of vulnerability points of the EA.

From the other side, since price dynamics is measured for each EA member, we also check how domestic (national) price dynamics influence current account (external) position of the analysed economies. Of course, expected relation is negative indicating that inflation rise initiates current account worsening. We don't investigate which factors are behind price dynamics, real factors such as productivity rise (known as Balassa-Samuelson effect) or it is abundant capital inflows (monetary factor). The authors generally observe price dynamics of the EA members, as the competitiveness independent variable at the national level. As previously mentioned, from the supranational level nominal euro exchange rate is taken as an independent variable, assumed to be closely related with competitiveness and, consequently, current account position.

Macro-panel data covers 12 EA members ( $\mathrm{N}$-dimension) in the time framework 1999Q1-2019Q4 (84 quarters as the T-dimension). The sample consists of the 12 initial members of the EA (so called, EZ12): Austria, Belgium, Finland, France, Germany, Luxembourg, Netherlands (mostly referred as the core), Greece, Spain, Portugal, Ireland and Italy (mostly referred as the periphery). For model estimation are used following quarterly variables: current account $-c a$ (\% of GDP, 
Non-Stationary Heterogeneous Panel Approach of Current Account Adjustments in the Euro-Area

source OECD), consumer price index - cpi (all prices, source IMF International Financial Statistics) and nominal euro exchange rate - neer (nominal effective exchange rate, index for EA, source IMF International Financial Statistics).

\subsection{Panel ARDL model: PMG vs. MG estimators}

One of the central findings from the large $\mathrm{N}$ and large $\mathrm{T}$ panel literature is that the assumption of homogeneity of slope parameters is often inappropriate ( $\mathrm{Im}$ et al, 2003; Loayza and Ranciere, 2005; Eberdhardt, 2012). Therefore, in this research authors apply the techniques proposed by Pesaran, Shin and Smith (1999) to estimate non-stationary dynamic panels in which the parameters are heterogeneous across units. Recent papers by Pesaran, Shin and Smith (1999) offer two important new techniques to estimate non-stationary dynamic panels in which the parameters are heterogeneous across groups: the Mean-Group (MG) and Pooled Mean-Group (PMG) estimators. MG is based on estimation of $\mathrm{N}$ time-series regressions and averages coefficients, while PMG is based on equal long-run relationship across all panel units and averaging of coefficients (short-run adjustments).

The choice among these estimators faces a general trade-off between consistency and efficiency (Pesaran and Smith, 1995). Hausman test is applied to distinguish whether restriction related to homogeneous long-run relationship in PMG model is true. If long-run relationship is homogeneous, namely, if the restriction in PMG model is true, the estimates are efficient and consistent (PMG method gives efficient and consistent estimates). In contrary, heterogeneous longrun equilibrium relationships mean inconsistent PMG estimates. MG model assumes heterogeneous long-run equilibrium relationships and provides consistent estimates in both cases (Blackburne and Frank, 2007). Short-run adjustments are heterogeneous in both models. PMG and MG estimators are particularly useful in exploring adjustment mechanisms within the monetary union when the long run is given by conditions expected to be homogeneous across countries, while the shortrun adjustment depends on member characteristics. The error correction (ec) coefficient or parameter (adjustment parameter or speed of adjustment) is expected to be significantly negative, in which case there is a long-term relation or convergence between the variables. Otherwise, there is no evidence of long-term relationship (Yuan-Ming and Wang, 2015; Glavaški and Beker Pucar, 2020).

The unrestricted specification for the Autoregressive Distributed Lag (ARDL) $\left(\mathrm{p}_{1}, \mathrm{q}_{2}, \ldots, \mathrm{q}_{\mathrm{k}}\right)$ dynamic specification form, for $\mathrm{t}=1,2, \ldots, \mathrm{T}$ time periods, $\mathrm{i}=1,2, \ldots, \mathrm{N}$ countries, for the dependent variable $\mathrm{Y}$ (Blackburne and Frank, 2007; Chu and Sek, 2015) is:

$$
y_{i t}=\sum_{j=1}^{p} \lambda_{i j}^{*} y_{i, t-j}+\sum_{j=0}^{q} \delta_{i j}^{*} X_{i, t-j}+\mu_{i}+\varepsilon_{i t}
$$

\section{DOI: $10.24818 / 18423264 / 55.1 .21 .12$}




\section{Emilija Beker Pucar, Olgica Glavaški}

where $X_{i, t-j}$ is the $(\mathrm{k} \times 1)$ vector of explanatory variables for the group $i$; $\delta_{i j}$ are the $\mathrm{k}-1$ coefficient vectors; $\lambda_{\mathrm{ij}}$ are scalars; and $\mu_{\mathrm{i}}$ is the group-specific effect. If the variables are, for example, I(1) and cointegrated, then the error term is an $\mathrm{I}(0)$ process for all $i$. A principal feature of cointegrated variables is their responsiveness to any deviation from long-run equilibrium. This feature implies an error correction model in which the short-run dynamics of the variables in the system are influenced by the deviation from equilibrium. Thus, it is common to reparameterize previous model into the error correction equation or a VECM system:

$$
\Delta y_{i t}=\phi_{i}\left(y_{i, t-j}-\theta_{i} X_{i t}\right)+\sum_{j=1}^{p-1} \lambda_{i j}^{*} \Delta y_{i, t-1}+\sum_{j=0}^{q-1} \delta_{i j}^{*} \Delta X_{i, t-j}+\mu_{i}+\varepsilon_{i t}
$$

In this research, current account position ( $c a$ ) represents the dependent variable, investigated in dependence from national consumer price index (cpi) and supranational nominal (euro) exchange rate (neer). Thus, model specification is as follows:

$$
\begin{gathered}
\Delta c a_{i t}=\phi_{i}\left(c a_{i t}-\theta_{i} c p i_{i t}-\theta_{i} n e e r_{i t}\right)+\sum_{j=1}^{p-1} \lambda_{i j}^{*} \Delta c a_{i, t-j}+ \\
\sum_{j=0}^{q-1} \delta_{i j}^{*} \Delta c p i_{i, t-j}+\sum_{j=0}^{q-1} \delta_{i j}^{*} \Delta n e e r_{i, t-j}+\mu_{i}+\varepsilon_{i t},
\end{gathered}
$$

where $\phi_{i}$ is the error-correction parameter, indicating speed of adjustment to longrun equilibrium relationship for each EA member; $\theta_{i}$ is the long run relationship between variables; $\lambda_{i j}^{*}$ is the coefficient of lagged dependent variable; $\delta_{i j}^{*}$ is short-run parameters for each EA member; $\mu_{i}$ represents individual effects. Error-correction $(e c)$ parameter, $\phi_{i}$, is the most important part of the model, showing speed of adjustment to long-run equilibrium relationship, in the case when $\phi_{i}$ is significantly negative.

The procedure performed in order to obtain final estimates of the above specified model concerning long-run and short-run dynamic relationships, as well as adjustments towards equilibrium (cointegration), consists from the following empirical steps (performed in software Stata 12 and Stata 15):

- Test of cross-sectional dependence (CSD) with the null hypothesis of independence between panels (Pesaran, 2004); the null is mostly rejected in macropanels, along with the expected finding of significant CSD in the case of highly integrated EA members;

- Panel unit root testing (PURT) performed with Pesaran (Pesaran, 2007) second generation panel stationarity test, since it accounts for previously confirmed CSD;

- Westerlund cointegration test between non-stationary I(1) variables, with the null hypothesis of no cointegration (Persyn and Westerlund, 2008);

- In the case of confirmed cointegration between I(1) variables of $c a, c p i$ and neer, the choice between MG and PMG estimators of panel ARDL model is made with Hausman specification test (Blackburne and Frank, 2007); 
Non-Stationary Heterogeneous Panel Approach of Current Account Adjustments in the Euro-Area

- Estimation of homogeneous long-run and heterogeneous (country specific) short-run coefficients and error-term speed of adjustment parameters with preferred estimator (Blackburne and Frank, 2007).

In the following section are given the results of above stated pre-estimation procedure (Table 1) and the results of estimated panel ARDL model with PMG estimator (Table 2 and 3).

\section{The results}

\subsection{Pre-estimation procedure}

Table 1 shows the results of pre-estimation procedure, namely the results of Pesaran CD test, Pesaran PURT test in the level and first differences of the variables, as well as Westerlund cointegration test. As mentioned in the previous section, estimation procedure for heterogeneous and non-stationary macro-panel models starts with CSD test. The null hypothesis of Pesaran CD test $\left(\mathrm{H}_{0}\right.$ : crosssectional independence) is tested against the alternative hypothesis $\left(\mathrm{H}_{1}\right.$ : crosssectional dependence between panels). The results confirm that for all examined variables (ca, cpi, neer), $p$-value indicates the rejection of the null, hence CSD is evident between EA members.

Since the sample consists of trade and financially integrated EA members, confirmed CSD is expected finding. Therefore, the only acceptable PURT is the second generation PURT which accounts for CSD. In this research is applied Pesaran PURT with the null hypothesis $-\mathrm{H}_{0}$ : all series are non-stationary. The results of the model with the constant, for variables in the level and at the first differences, indicate the acceptance of the null (Table 1).

Table 1. Pesaran CD test, Pesaran PURT tests and Westerlund cointegration test

\begin{tabular}{|c|c|c|c|c|c|c|c|c|}
\hline \multirow{2}{*}{$\begin{array}{c}\text { Variable } \\
\text { s }\end{array}$} & \multicolumn{2}{|c|}{$\begin{array}{l}\text { Pesaran } \\
\text { CD test }\end{array}$} & \multicolumn{2}{|c|}{$\begin{array}{l}\text { Pesaran PURT } \\
\text { in the level }\end{array}$} & \multicolumn{2}{|c|}{$\begin{array}{c}\text { Pesaran PURT } \\
\text { at the first } \\
\text { differences }\end{array}$} & \multicolumn{2}{|c|}{$\begin{array}{c}\text { Westerlund } \\
\text { cointegration } \\
\text { test }\end{array}$} \\
\hline & CD-test & $\mathrm{p}$ & $\mathrm{Z}(\overline{\mathrm{t}})$-stat & $\mathrm{p}$ & $\mathrm{Z}(\overline{\mathrm{t}})$-stat & $\mathrm{p}$ & Stat & $\mathrm{p}$ \\
\hline$c a$ & 3.03 & 0.002 & -0.780 & 0.218 & -16.164 & 0.000 & \multirow{3}{*}{-2.4618} & \multirow{3}{*}{0.0069} \\
\hline$c p i$ & 67.98 & 0.000 & 2.086 & 0.981 & -13.377 & 0.000 & & \\
\hline neer & 70.58 & 0.000 & 16.711 & 1.000 & 16.711 & 1.000 & & \\
\hline
\end{tabular}

Note: the variable ezneer, due to the uniformity at the EA level show the signs of non-stationarity in the level (with the same values) and non-stationarity at the first differences within the PURT framework; however, at the time series framework these time series are confirmed to be nonstationary in the level and stationary after differencing (these results are available upon request to the authors).

Source: authors' estimations

Before the estimation of heterogeneous, dynamic and non-stationary macropanel model it is necessary to identify is there a long-run equilibrium relationship

DOI: $10.24818 / 18423264 / 55.1 .21 .12$ 


\section{Emilija Beker Pucar, Olgica Glavaški}

(cointegration) between observed variables. Namely, if the cointegration doesn't exist between non-stationary I(1) variables, then the estimation procedure could be directed towards alternative estimators of heterogeneous and non-stationary panels, such as CCE (Common Correlated Effects) MG or Augmented Mean Group (AMG) estimators (Eberdhardt, 2012). At the same time, cointegration between current account, price dynamics and supranational nominal (euro) exchange rate, has been expected having in mind that the EA is grounded at the process of monetary and real convergence of its members. Westerlund cointegration test with the null $\mathrm{H}_{0}$ : no cointegration, against $\mathrm{H}_{1}$ : some panels are cointegrated, gives the $p$ values which signifies the rejection of the null (Table 1 , the last column). Therefore, at least some panels are cointegrated. In order to identify where cointegration and adjustment towards long-run equilibrium could be found between current account, consumer price index and nominal euro exchange rate of selected EA members, it is proceeded in the direction of PMG and MG estimators.

\subsection{The discussion of the final results}

Since PMG and MG estimators both serve as estimators for heterogeneous, non-stationary and dynamic macro-panel model, it is necessary to decide which estimator is more acceptable. Before Hausman test of specification, it is necessary to select the lag length for both MG and PMG based at the Schwarz Bayesian Criterion (SBC) and Akaike Information Criterion (AIC). The best combination of ARDL is chosen based on the their smallest values, in this case ARDL $(1,0,0)$.

According to Hausman (1978), the hypothesis of homogeneity of the longrun policy parameters cannot be assumed apriori. The effect of heterogeneity on the means of the coefficients can be determined by Hausman specification test. If the parameters are de facto homogenous, the PMG estimates are more efficient than MG ( $p$-value above 0.05). In other words, the efficient estimator under the null hypothesis which is PMG has been preferred. However, if the null hypothesis is rejected, then the efficient estimator MG is preferred ( $p$-value below 0.05). Since the $p$-value is 0.12 , the null hypothesis of homogeneity cannot be rejected (Table 2 ). The results, thus, supports PMG estimator as an efficient estimator under the null hypothesis for the ARDL $(1,0,0)$ model.

Table 2. Estimated homogeneous coefficients of PMG and MG estimators for the EA12 in the period 1999Q1-2019Q4

\begin{tabular}{|c|c|c|c|}
\hline ARDL & $\begin{array}{c}\text { Homogeneous long-run } \\
\text { relationship }\end{array}$ & Short-run relationship & $\begin{array}{c}\text { Error } \\
\text { correction }\end{array}$ \\
\hline
\end{tabular}


Non-Stationary Heterogeneous Panel Approach of Current Account Adjustments in the Euro-Area

\begin{tabular}{|c|c|c|c|c|c|c|c|c|c|c|}
\hline \multirow[t]{2}{*}{$(1,0,0)$} & & & & & & & & & \multicolumn{2}{|c|}{ term } \\
\hline & cpi & $\mathrm{p}$ & neer & $\mathrm{p}$ & $\Delta \mathrm{cpi}$ & $\mathrm{p}$ & $\begin{array}{c}\Delta \text { nee } \\
\mathrm{r}\end{array}$ & $\mathrm{p}$ & ec & $\mathrm{p}$ \\
\hline PMG & -0.053 & 0.010 & $\begin{array}{c}- \\
0.038\end{array}$ & 0.067 & $\begin{array}{c}- \\
0.589\end{array}$ & 0.030 & $\begin{array}{c}- \\
0.020\end{array}$ & 0.738 & $\begin{array}{c}- \\
0.384\end{array}$ & 0.001 \\
\hline MG & 0.154 & 0.148 & -0.145 & 0.053 & $\begin{array}{c}- \\
0.656\end{array}$ & 0.025 & $\begin{array}{c}- \\
0.011\end{array}$ & 0.866 & $\begin{array}{c}- \\
0.514\end{array}$ & 0.000 \\
\hline $\begin{array}{l}\text { Hausman } \\
\text { test: } \\
\chi^{2}(2)=4.21 \\
p=0.1221\end{array}$ & \multicolumn{10}{|c|}{ PMG estimator, the efficient estimator under the null hypothesis, is preferred. } \\
\hline
\end{tabular}

Source: authors' estimations.

In the short-run, external position is determined with domestic price dynamics (significantly negative coefficient), while the impact of nominal exchange rate (although with the right sign) is not statistically significant. This could be interpreted in the sense that external position of the EA members is mostly influenced with the domestic factors which affect overall price level, while supranational indicator of competitiveness (euro weakening or strengthening) doesn't express a significant impact, at least in the short run. In the long-run and for a whole sample of EA12 members, estimated homogeneous long-run coefficients imply that the current account of EZ12 members is worsened as a result of nominal (euro) exchange rate appreciation and domestic inflation increase. Is this long-run relationship sustainable is judged with error-correction term which indicates the speed of adjustment to restore equilibrium in the dynamic model. Highly significant error-correction term in the range $-1<e c<0$ implies that there is a steady-state equilibrium in the long-run between variables i.e. the system is converging to equilibrium and the estimated model is stable. Error-correction term is significantly negative (-0.39) indicating that current accounts of EA12 members adjust towards long-run equilibrium at 39\% speed of adjustment every quarter. Estimated homogeneous long-run coefficients, along with error correction term for the whole EA sample, confirm the adjustment towards equilibrium (long-run causality) as a confirmation of previously found cointegrating relationship.

Table 3. Estimated heterogeneous coefficients for the EZ12 in the period 1999Q1-2019Q4 
Emilija Beker Pucar, Olgica Glavaški

\begin{tabular}{|c|c|c|c|c|c|c|}
\hline \multirow[t]{2}{*}{ member } & \multicolumn{6}{|c|}{ Independent variable: cpi, neer } \\
\hline & $e c\left(\phi_{i}\right)$ & $p$ & $\Delta c p i$ & $p$ & sezneer & $p$ \\
\hline Austria & -0.185 & 0.002 & -0.038 & 0.894 & 0.015 & 0.784 \\
\hline Belgium & -0.752 & 0.000 & -0.498 & 0.453 & 0.115 & 0.399 \\
\hline Finland & -0.160 & 0.005 & 0.157 & 0.683 & 0.079 & 0.286 \\
\hline France & -0.529 & 0.000 & -0.009 & 0.954 & 0.016 & 0.571 \\
\hline Germany & -0.048 & 0.041 & 0.028 & 0.891 & 0.026 & 0.508 \\
\hline Luxembourg & -0.980 & 0.000 & -2.04824 & 0.346 & -0.676 & 0.140 \\
\hline Netherlands & -0.770 & 0.000 & -1.508 & 0.025 & 0.072 & 0.676 \\
\hline Greece & -0.066 & 0.152 & -0.103 & 0.575 & -0.085 & 0.408 \\
\hline Spain & -0.002 & 0.851 & -0.150 & 0.034 & 0.031 & 0.309 \\
\hline Portugal & -0.014 & 0.520 & -0.022 & 0.884 & 0.065 & 0.223 \\
\hline Ireland & -1.069 & 0.000 & -2.656 & 0.033 & 0.022 & 0.960 \\
\hline Italy & -0.026 & 0.432 & -0.222 & 0.286 & 0.069 & 0.018 \\
\hline
\end{tabular}

Note: error correcting speed of adjustment term - ec $\left(\Phi_{i}\right)$ - is highlighted if it is significantly negative in the range $-1<e c<0$, under the prior assumption that the variables show a return to a long-run equilibrium.

Source: authors' estimations.

However, the results of estimated heterogeneous coefficients for each of 12 EA analysed country, show rather heterogeneous and less straightforward results. Generally speaking, current account balance is not significantly determined with domestic price dynamics in the short-run (with the exception of Netherlands, Spain and Ireland), while euro exchange rate also doesn't cause significantly changes of the current accounts (with the exception of Italy). Dominantly insignificant shortrun coefficients doesn't support short-run causality of the estimated ARDL $(1,0,0)$ model, estimated with PMG estimator. However, if we focus at individual errorcorrection terms for the EA12, the adjustment towards equilibrium is confirmed for Austria, Belgium, Finland, France, Germany, Luxembourg and Netherlands, i.e. for the EA core. From the other side, in the case of EA periphery (Greece, Spain, Portugal, Ireland, Italy) adjustments towards the equilibrium (according the error correction term) are not detected. This finding highlights and underpins the core- 
Non-Stationary Heterogeneous Panel Approach of Current Account Adjustments in the Euro-Area

periphery dualism concerning EA heterogeneity of external positions and competitiveness, as well as diverging position of the EA periphery.

\section{Concluding remarks}

In this paper is explored heterogeneity of external (current account) positions and adjustments of initial 12 EA core and periphery members. Current account position is observed in relation with two important factors of competitiveness: (i) national indicator of price dynamics; (ii) supranational indicator of nominal euro exchange rate. From the aspect of sustainable monetary union it would be preferable that current account, as a national indicator of external position, converge towards alignment in the long-run. Since EA members practically sacrifice national monetary policy including exchange rate policy, the improvement of current account position through exchange rate channel can be achieved only via euro weakening. From the other side, price dynamics as a national indicator should be kept under control in order to maintain or restore competitiveness and current account balance. Having in mind the loss of above mentioned counter-cyclic instruments of economic policy, fiscal and structural policies should be disciplined enough not to initiate price divergences within the EA. Price divergences were considered as the trigger for further macroeconomic asymmetries of internal (inflation and real economy) and external (current account) positions.

In this research the authors try to shed more light into the issue of current account balance as an independent variable and national price dynamics and supranational (nominal euro) exchange rate as explanatory variables. The estimation of heterogeneous, dynamic and non-stationary macro-panel model of initial 12 EA members in the period 1999Q1-2019Q4 allows us to distinguish between long-run and short-run dynamics at the EA level, as well as at the level of each member in the sample. The pre-estimation procedure of cross-sectional (in)dependence, PURT, cointegration test, as well as Hausman specification test, indicated that PMG estimator is preferred. The results support long-run causality and adjustment in the estimated ARDL $(1,0,0)$ model, while short-run causality is rather weak and heterogeneous. As expected, current account at the EA level worsens in the long-run if euro nominally appreciate or if domestic prices rise. While the external position of the EA core aligns towards equilibrium, the external position of the periphery doesn't converge significantly towards the equilibrium. The findings thus underpin one aspect of widely known phenomenon of 'coreperiphery dualism', here in the sense of external macroeconomic asymmetry.

Since the 'core-periphery dualism" comprises other macroeconomic asymmetries, along with here investigated external position, in the sake of EA sustainability it is necessary to restrain diverging price dynamics and to strengthen the role of unified EA monetary variables (such as the role of common interest rate channel and exchange rate channel) in the short-run, as well as in the long-run. In

DOI: 10.24818/18423264/55.1.21.12 


\section{Emilija Beker Pucar, Olgica Glavaški}

order to achieve necessary convergence and reduce EA heterogeneity, the root of the dualism could be found in incompleteness of the EA without banking, fiscal or even political union. The status quo phase implies at least enough discipline of national economic authorities to avoid macroeconomic overheating with current account worsening of the weaker/periphery members. And vice versa, the automatic adjustment mechanism within the monetary union as a rigid exchange rate regime, should be fully operative in order to balance asymmetric external positions.

\section{REFERENCES}

[1] Acocella, N., Pasimeni, P. (2018), The 'Uncovered Inflation Rate Parity' Condition in Monetary Union. Forum for Macroeconomics and Macroeconomic Policies Working Paper 28;

[2] Beker Pucar, E., Glavaški, O. (2020a), The Role of Exchange Rate on the Road towards the Euro Area: The Case of Baltic and Central Emerging European Economies. Economicky Časopis, 68(3), 289-317;

[3] Beker Pucar, E., Glavaški, O. (2020b), Macroeconomic External (Im)balances withing the Eurozone: Core vs Periphery. Economic Themes, 17(1): 27-41;

[4] Blackburne, E. F., Frank, M. W. (2007), Estimation of Nonstationary Heterogeneous Panels, The Stata Journal, 7(2): 197-208;

[5] Blanchard, O. J., Giavazzi, F. (2002), Current Account Deficits in the Euro Area: The End of the Feldstein Horioka Puzzle? Brookings Papers on Economic Activity, 33(2): 147-210;

[6] Chen, R., Milesi-Ferretti, G. M., Tressel, T. (2012), External Imbalances in the Euro Area. International Monetary Fund Working Paper 12/236;

[7] De Grauwe, P. (2018), Core-periphery in the Eurozone. Paper presented at the Future of Central Banking in Honour of Vitor Constancio, Frankfurt;

[8] Eberdhardt, M. (2012), Estimating Panel Time-Series Models with Heterogeneous Slopes. The Stata Journal, 12: 61-71;

[9] Estrada, A., Gali, J., Lopez-Salido, D. (2013), Patterns of Convergence and Divergence in the Euro Area. Barcelona Graduate School of Economics Working Paper 722;

[10] Glavaški, O., Beker Pucar, E. (2020), Fiscal Adjustments in the European Union versus West Balkans Economies: Evidence from

Heterogeneous Panels. Economic Analysis, 57(3): 257-272;

[11] Hausman, J. A. (1978), Specification Tests in Econometrics.

Econometrica, 46(6): 1251-1272;

[12] Im, K. S., Pesaran, M. H., Shin, Y. (2003), Testing for Unit Roots in Heterogeneous Panels. Journal of Econometrics, 115: 53-74;

[13] Johnston A., Regan, A. (2016), European Monetary Integration and the Incompatibility of National Varieties of Capitalism. Journal of Common Market Studies, 54(2): 318-336; 
Non-Stationary Heterogeneous Panel Approach of Current Account Adjustments in the Euro-Area

[14] Karanasos, M., Koutroumpis, P., Karavias, Y., Kartsaklas, A., Arakelian, V. (2016), Inflation Convergence in the EMU. Journal of Empirical Finance, 39: 241-253;

[15] Lane P. R., McQuade, P. (2013), Domestic Credit Growth and International Capital Flows; European Central Bank Working Paper 1566;

[16] Loayza, N., Ranciere, R. (2005), Financial Development, Financial Fragility, and Growth. IMF Working Paper 05/70;

[17] Marjanac, D. (2020), The Effect of the Exchange Rate System on

Economic Growth of Bosnia and Herzegovina. The Annals of the Faculty of

Economics in Subotica, 56(43): 49-65;

[18] Persyn, D., Westerlund, J. (2008), Error-Correction-Based

Cointegration Tests for Panel Data. The Stata Journal, 8: 232-241;

[19] Pesaran H., Shin, Y., Smith, R. (1999), Pooled Mean Group Estimation of Dynamic Heterogeneous Panels. Journal of the American Statistical Association, 94: 621-634;

[20] Pesaran H., Smith, R. (1995), Estimating Long-Run Relationships from Dynamic Heterogeneous Panels. Journal of Econometrics, 68: 79-113;

[21] Pesaran, M. H. (2004), General Diagnostic Tests for Cross Section Dependence in Panels. CESifo Working Paper 1229;

[22] Pesaran, M. H. (2007), A Simple Panel Unit Root Test in the Preference of Cross Section Dependence. Journal of Applied Econometrics, 22: 265-312;

[23] Pierluigi, B., Sondermann, D. (2018), Macroeconomic Imbalances in the Euro Area: Where Do We Stand? European Central Bank Occasional Paper 211.

[24] Tokarski, P. (2019), Divergence and Diversity in the Euro Area. SWP Research Paper 2019/RP 06.

[25] Yuan-Ming, Ll, Wang, K-M. (2015), Dynamic Heterogeneous Panel Analysis of the Correlation between Stock Prices and Exchange

Rates; Economic Research-Ekonomska Istraživanja, 28(1): 749-772. 